\title{
Recycling Crushed Waste Beer Bottle Glass in Fired Clay Bricks
}

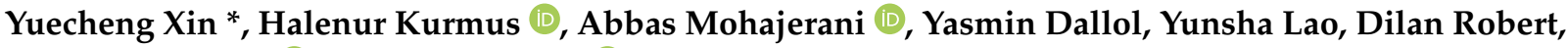 \\ Biplob Pramanik (1) and Phuong Tran (1)
}

School of Engineering, RMIT University, Melbourne 3000, Australia; s3432918@student.rmit.edu.au (H.K.); abbas.mohajerani@rmit.edu.au (A.M.); dallol1505@gmail.com (Y.D.); yunshalao@gmail.com (Y.L.); dilan.robert@rmit.edu.au (D.R.); biplob.pramanik@rmit.edu.au (B.P.); jonathan.tran@rmit.edu.au (P.T.)

* Correspondence: s3535800@student.rmit.edu.au

Citation: Xin, Y.; Kurmus, H.; Mohajerani, A.; Dallol, Y.; Lao, Y.; Robert, D.; Pramanik, B.; Tran, P. Recycling Crushed Waste Beer Bottle Glass in Fired Clay Bricks. Buildings 2021, 11, 483. https://doi.org/ 10.3390/buildings 11100483

Academic Editors: Łukasz Sadowski and Walid Maherzi

Received: 27 August 2021

Accepted: 15 October 2021

Published: 17 October 202

Publisher's Note: MDPI stays neutral with regard to jurisdictional claims in published maps and institutional affiliations.

Copyright: (c) 2021 by the authors. Licensee MDPI, Basel, Switzerland. This article is an open access article distributed under the terms and conditions of the Creative Commons Attribution (CC BY) license (https:/ / creativecommons.org/licenses/by/ $4.0 /)$.
Abstract: Waste glass is a readily available domestic material. Each year, around 257,000 tonnes of glass waste are produced in Victoria, and the majority is glass packings. Typically, mixed waste glass cullet is deposited in landfills due to the limited recycling techniques. As a result, landfills are facing a growing issue. Therefore, this study investigates the addition of waste beer bottle glass (BG) in fired clay bricks and examines the effects of varying firing temperatures on the physical and mechanical properties of the manufactured samples. Clay bricks containing $10 \% \mathrm{BG}$ at a firing temperature of $950{ }^{\circ} \mathrm{C}$ depicted similar compressive strength results $(41 \mathrm{MPa})$ to the control samples (42 MPa). The results of all tested bricks were found to be below the water absorption limit of $17 \%$. The thermal conductivity of the bricks incorporating BG was investigated, and it was found that the thermal performance improved with the decreasing firing temperature. Moreover, an initial rate of absorption (IRA), XRD, and XRF analysis was conducted. The experimental results have been discussed and compared with the recommended acceptable properties for standard bricks.

Keywords: waste glass; recycling; fired clay bricks; physical and mechanical properties; sustainability; construction materials

\section{Introduction}

Bricks are used as an essential construction material and are utilised prominently around the world. The global production of bricks is around 1500 billion annually [1]. However, the PWC report indicated that Melbourne is facing a clay shortage. The cumulative demand for the clay and clay shale from 2015 to 2050 is 40,062,953 tonnes, but the supply volumes from 2015 to 2025 are 19,061,236 tonnes [2]. Additionally, a single brick creates $0.61 \mathrm{~kg}$ of $\mathrm{CO}_{2}$ over its life cycle. In addition, the firing process of 250 billion bricks releases 40.65-42.64 $\mathrm{Tg} \mathrm{CO}_{2}$ approximately into the atmosphere annually when considering the clay burning and coal combustion [3]. Large amounts of $\mathrm{CO}_{2}$ emissions are harmful to the environment, which results in climate warming. As a result, incorporating wastes into bricks tends to be a method for addressing the pollution problem. Components such as rice husks, rubber, sawdust, various types of sludge, and recycled paper have proved beneficial to the environment and the final product. For instance, Chiang et al. [4] focused on adding water treatment sludge and rice husk into bricks to achieve lightweight bricks while addressing the stockpile issue. In 2012, the study indicated that the foundry by-products could potentially produce ceramic bricks with properties satisfying the standard limits [5]. In 2019, to address the stockpile issue caused by wastewater sludge, researchers proposed the addition of treated wastewater sludge in fired-clay bricks with promising results [6].

Vlasove et al. [7] stated that the main issues relative to brick manufacturing include the high energy consumption, water usage, and the processing of large-scale wastes (ecological problem). Red clay bricks, red clay-milled cullet mixture bricks, red clay-milled basalt mixture bricks, and red clay-milled glass-milled basalt mixture bricks were investigated by Vlasove et al. The results proved that double and triple composition of low melting 
point glass dropped sintering time to $8-12 \mathrm{~h}$ and reduced the sintering temperature of 900-1000 ${ }^{\circ} \mathrm{C}$ while maintaining good strength of bricks. In addition, Phonphuak et al. [8] compared the physical-mechanical properties of bricks incorporating waste glass to controlled bricks. The study aimed to reduce the firing temperature of bricks to save energy and was performed by incorporating $0.5 \%$ and $10 \%$ glass in fired clay bricks, with the firing temperature ranging from 900 to $1000{ }^{\circ} \mathrm{C}$. The results revealed that the glass additive sodium oxide $\left(\mathrm{Na}_{2} \mathrm{O}\right)$, which has a non-crystalline composition, assisted in reducing the temperature required for sintering the bricks. Increasing the glassy phase in the brick enhanced the structural and durability properties and reduced the manufacturing costs. It also induced vitrification in the bricks, resulting in higher density, reducing water absorption, and lowering the drying shrinkage.

In many studies, beer bottles were used as waste glass additives because they are accessible, cheap, and have a low melting point of around $1000{ }^{\circ} \mathrm{C}$. According to the Netbalance report [9], about 257,000 tonnes of glass waste are generated each year. The majority is from glass packages such as glass bottles, beads, and bowls. Landfills are facing major space availability issues. Therefore, it is becoming crucial to find effective and efficient ways to recycle waste glass. An alternative to a growing waste issue may be recycling waste bottle glass into building materials such as fired clay bricks. Beer bottles are mainly comprised of soda-lime, which has a melting point approximately half that of sand. Therefore, the soda portion of the glass contributes to a low melting point, making it potentially recyclable, and the lime portion fortifies the glass by increasing its hardness and durability.

Therefore, this study aims to investigate the potential of recycling waste beer bottle glass (BG) in fired clay bricks. Fired clay bricks containing 10\% (by weight) of crushed waste BG were prepared and compared to controlled bricks. Moreover, to study the effects of varying firing temperatures on the physical and mechanical properties and thermal conductivity of the manufactured samples, a temperature range between 900 to $1050{ }^{\circ} \mathrm{C}$ was selected. Additionally, numerous tests were carried out, including compressive strength, water absorption, shrinkage, the initial rate of absorption (IRA), X-ray fluorescence (XRF), and $\mathrm{X}$-ray diffraction analysis (XRD). The experimental results have been discussed and compared with the recommended acceptable limits for standard bricks.

\section{Materials and Methods}

A trusted brick manufacturer provided the clay soils (PGH Bricks and Pavers Victoria). In total, around $30 \mathrm{~kg}$ of soil sample was used to produce the required amount of brick samples. Table 1 shows the geotechnical properties of the brick soil used in this study. The clay soil was initially collected in metal trays (Figure 1a) and oven-dried at $105^{\circ} \mathrm{C}$ for $24 \mathrm{~h}$. The soil was crushed using a hammer and sieved using $200 \mu \mathrm{m}$ sieves. Moreover, nineteen $330 \mathrm{~mL}$ recyclable beer bottles were collected for this study, which were provided from a local restaurant chain, and the chosen brand was Tsingtao beer (Figure 1b). Firstly, the tags on the surface of each BG were removed by using a steel brush and water. Clean glass bottles were oven-dried for $30 \mathrm{~min}$ at $105^{\circ} \mathrm{C}$. After oven drying, a hammer was used to crush the BG into fragments. Next, the ball mill was used for $24 \mathrm{~h}$ to crush the BG fragments to BG powder (particle size: $<0.2 \mathrm{~mm}$ ). In addition, XRD (D8 Endeavor, Bruker, Billerica, MA, USA) was utilised to identify the main crystalline phases. XRF (S4 Pioneer, Bruker, Billerica, MA, USA) analysis was conducted to determine the major chemical components and oxides of the experimental clay soil and BG powder. Mixture proportions of specimens by weight $(\mathrm{g})$ and the firing temperature were summarized in Table 2. 
Table 1. Geotechnical properties of the brick soil [6].

\begin{tabular}{cc}
\hline Properties & Brick Soil \\
\hline Liquid limit (\%) & 32 \\
\hline Plastic Limit (\%) & 19 \\
\hline Plasticity Index (\%) & 13 \\
\hline
\end{tabular}

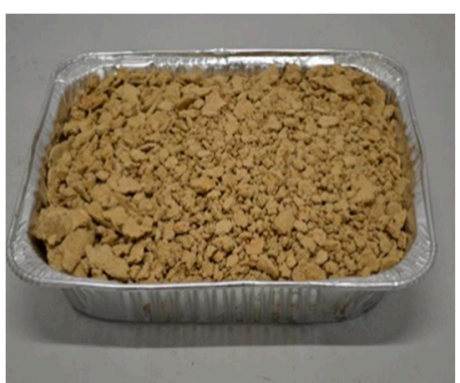

(a)

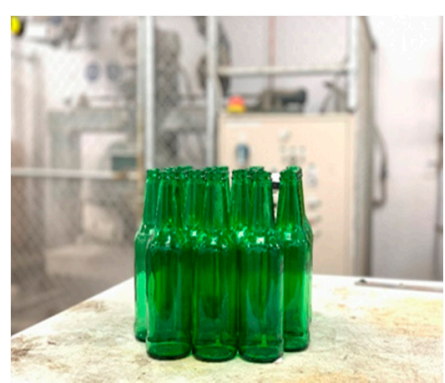

(b)

Figure 1. (a) Clay soil; (b) Beer bottles used in this study.

Table 2. Mixture proportions of specimens by weight $(\mathrm{g})$ and the firing temperature.

\begin{tabular}{cccc}
\hline Set Number & Qty. of Samples & $\begin{array}{c}\text { BG Content } \% \\
\text { (by Weight) }\end{array}$ & Firing Temperature \\
\hline S1 & 6 & $10 \%$ & $1050{ }^{\circ} \mathrm{C}$ \\
\hline S2 & 6 & $10 \%$ & $1000{ }^{\circ} \mathrm{C}$ \\
\hline S3 & 6 & $10 \%$ & $950{ }^{\circ} \mathrm{C}$ \\
\hline S4 & 6 & $10 \%$ & $900^{\circ} \mathrm{C}$ \\
\hline S5 (control) & 6 & $0 \%$ & $1050^{\circ} \mathrm{C}$ \\
\hline
\end{tabular}

\subsection{Brick Sample Preparation}

Primarily, five sets of six bricks were prepared, resulting in thirty bricks. Sets 1, 2,3 , and 4 had the same moisture content of $15 \%$ and $10 \%$ BG, which were fired at temperatures of $1050,1000,950$, and $900{ }^{\circ} \mathrm{C}$, respectively. Set 5 was treated as the control batch $(0 \% \mathrm{BG})$ and was fired at $1050{ }^{\circ} \mathrm{C}$. According to [10], the optimum moisture content $(\mathrm{OMC})$ was found to be $15 \%$. The soil, BG, and water mixtures were mixed using a 20 L Hobart mechanical mixer (MAESTRO MIX, Offenburg, Germany) for 20 min to ensure that the mixture was combined well. The mixture was then compacted using an IPC Global Servopac Gyratory Compactor (Figure 2a) under a pressure of $240 \mathrm{kPa}$, 20 gyrations/minute at a 3 degree angle. A mould of $100 \mathrm{~mm}$ diameter and $50 \mathrm{~mm}$ height was used. A similar process was performed for set 5 (control brick) other than the addition of BG in the mixture. All bricks were oven-dried for $24 \mathrm{~h}$ at $105^{\circ} \mathrm{C}$, followed by air-drying for $48 \mathrm{~h}$. The control bricks were placed into a furnace (Model KC 220/13, Hylec Controls Pty Ltd., NSW, Australia) (Figure 2b) with a ramp rate of $0.7^{\circ} \mathrm{C} / \mathrm{min}$ at $1050^{\circ} \mathrm{C}$ and kept at this temperature for $3 \mathrm{~h}$. The remaining five batches were placed in a furnace with a ramp rate of $0.7^{\circ} \mathrm{C} / \mathrm{min}$ at temperatures $900,950,1000$, and $1050^{\circ} \mathrm{C}$. After firing, the bricks remained in the furnace until all bricks cooled down to room temperature. All bricks were fired in the same furnace (Model KC 220/13, Hylec Controls Pty Ltd., NSW, Australia) to ensure consistency. The controlled brick samples were compared to the BG modified bricks to verify whether the addition of BG has the potential to decrease firing temperature. 


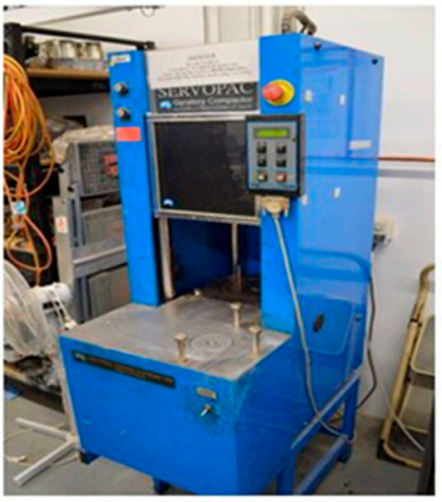

(a)

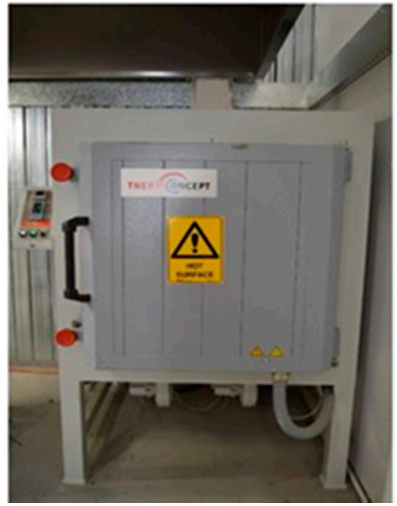

(b)

Figure 2. (a) Servopac gyratory compactor; (b) electric furnace.

\subsection{Compressive Strength Test}

The compressive strength test was carried out using a Tecnotest machine (K300/EUT, Tecnotest, Bg, Italy) (Figure 3) and TCM (Tecnotest computerised machine) software. Hence, the maximum load and compressive strength of each brick sample were determined. The compressive strength (MPa) calculations were conducted by considering the total load $(\mathrm{P})$ at which the specimen fails $(\mathrm{kN})$, area $(\mathrm{A})\left(\mathrm{mm}^{2}\right)$, and the aspect ratio factor $\left(\mathrm{K}_{\mathrm{a}}\right)$ (was derived according to [11], which was 0.53 ).

$$
\text { Compressive strength }=K_{a} \frac{1000 P}{A}
$$

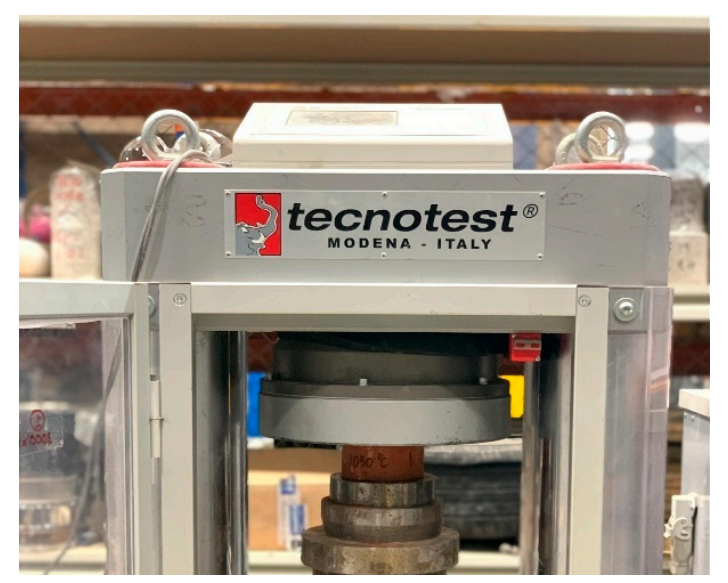

Figure 3. Tecnotest machine (K300/EUT).

\subsection{Shrinkage}

According to [12], the dimensions of each manufactured brick were recorded at the time after compaction, drying, and firing, respectively. These three sets of measurements have been analysed to determine the level of shrinkage.

\subsection{Thermal Conductivity}

Thermal conductivity is an essential criterion for building materials. The density affects the thermal conductivity performance. A transient line source (TLS) meter (TLS-100, Poly Technologies, Australia) was used to perform the thermal conductivity test, shown in Figure 4. A $4 \mathrm{~mm}$ (diameter) hole was drilled at the centre of the brick specimen, and a sensor needle (4 $\mathrm{mm}$ in diameter and $50 \mathrm{~mm}$ in length) was inserted in the hole completely. The measurements were carried out at an average temperature of $20 \pm 2{ }^{\circ} \mathrm{C}$. The test was 
performed three times for each sample, the mean of the three measurements was adopted, and $15 \mathrm{~min}$ interval time was applied between each test.

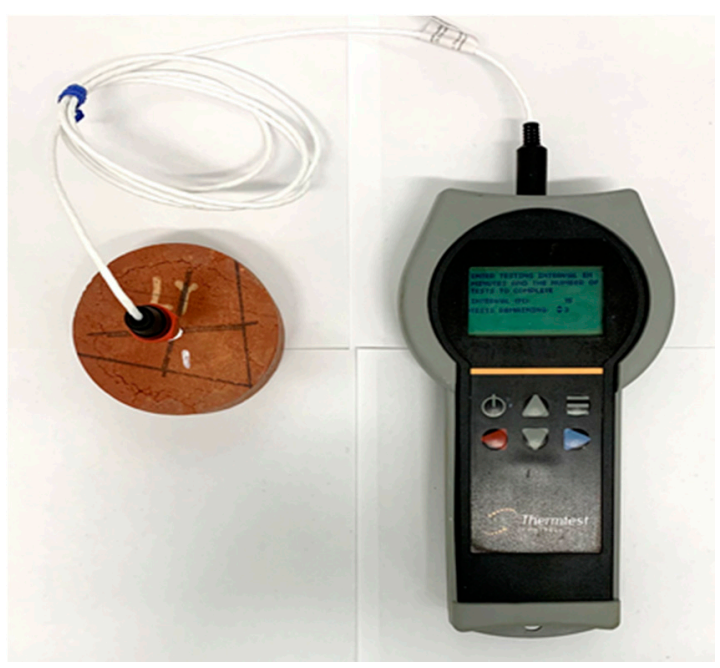

Figure 4. Thermal conductivity test.

\subsection{Water Absorption Test}

\subsubsection{Initial Rate of Absorption (Suction)}

According to [13], the weight of the specimen after oven-drying was recorded as $m_{1}$. The following step was to place the bed surface of the dry specimen on the bars for a period of $60 \pm 1 \mathrm{~s}$, measured from the time the specimen made contact with the water. During this time, the water was kept at a level of $3 \pm 1 \mathrm{~mm}$ above the bars. The next step was to remove the specimen from the water and immediately wipe it with a damp cloth and determine its mass ( $\mathrm{m}_{2}$ in grams). The weighing was completed within $1 \mathrm{~min}$ of the removal of the specimen from the water tank. Thus, the IRA was calculated using the following equation:

$$
\text { IRA }_{\text {gross }}=\frac{1000\left(\mathrm{~m}_{2}-\mathrm{m}_{1}\right)}{\mathrm{A}_{\text {gross }}}
$$

where

$$
\begin{aligned}
& \text { IRA = initial rate of absorption } \\
& \mathrm{m}_{1}=\text { mass of specimen oven-dry }(\mathrm{g}) \\
& \mathrm{m}_{2}=\text { mass of specimen after } 1 \text { min absorption }(\mathrm{g}) \\
& \mathrm{A}_{\text {gross }}=\text { gross area of the bed, based on work size dimensions }\left(\mathrm{mm}^{2}\right)
\end{aligned}
$$

\subsubsection{Coldwater $24 \mathrm{~h}$ Immersion Test}

The specimens were oven-dried for $24 \mathrm{~h}$ at $105^{\circ} \mathrm{C}$ after the initial rate of absorption test. The samples were weighed after they were fired and then cooled down to room temperature and recorded as $\mathrm{m}_{1}$. Then, the bricks were placed into cold water at ambient temperature for $24 \mathrm{~h}$. After $24 \mathrm{~h}$, they were removed from the cold water and drained for $1 \mathrm{~min}$, any remaining water on the bricks' surface was dried with a damp paper during the $3 \mathrm{~min}$, and the bricks were weighed again and recorded as $\mathrm{m}_{2}$. According to [14], the cold-water absorption (\%) can be calculated by the following equation:

$$
\mathrm{W}_{\mathrm{i}}=\frac{100\left(\mathrm{~m}_{2}-\mathrm{m}_{1}\right)}{\mathrm{m}_{1}}
$$

where

$\mathrm{m}_{1}=$ mass of specimen oven-dry $(\mathrm{g})$

$\mathrm{m}_{2}=$ mass of immersed surface dried specimen $(\mathrm{g})$

$\mathrm{W}_{\mathrm{i}}=$ percentage cold water immersion absorption of the specimen (\%) 


\subsubsection{Five-Hour Boiling Test}

On completion of the cold-water test, the specimens were placed on the grid in the water bath, and all surfaces of the specimens were covered by at least $25 \mathrm{~mm}$ of water. When the specimen was covered to the required depth, the water was rapidly heated to $100{ }^{\circ} \mathrm{C}$ in approximately $1 \mathrm{~h}$ and maintained at this temperature for $5 \mathrm{~h}$. At the end of this period, the specimen was cooled uniformly and left in the tank for more than $3 \mathrm{~h}$. The next step involved removing the bricks from the cold water, draining for $1 \mathrm{~min}$, and removing any remaining water on the bricks' surface using damp paper within $3 \mathrm{~min}$. The bricks were weighed again and recorded $\left(\mathrm{m}_{3}\right)$. According to Australian Standards [14], the following equation was used to calculate the boiling water absorption (\%);

$$
\mathrm{W}_{\mathrm{b}}=\frac{100\left(\mathrm{~m}_{3}-\mathrm{m}_{1}\right)}{\mathrm{m}_{1}}
$$

where

$\mathrm{m}_{1}=$ mass of dried specimen $(\mathrm{g})$

$\mathrm{m}_{3}=$ mass of the boiling surface dried specimen $(\mathrm{g})$

$\mathrm{W}_{\mathrm{b}}=$ percentage boiling water absorption of the specimen

\section{Results and Discussion}

\subsection{Chemical Analysis of Raw Materials}

Chemical analyses were conducted to obtain the chemical composition of the brick soil using XRF. Table 3 showed the main compound found in the soil and BG powder was silicon ( $\mathrm{Si}$ ). In comparison to clay, $\mathrm{BG}$ was found to have a higher concentration of sodium oxide $\left(\mathrm{Na}_{2} \mathrm{O}\right)$, a lower concentration of potassium oxide $\left(\mathrm{K}_{2} \mathrm{O}\right)$, and a lower concentration of aluminium oxide $\left(\mathrm{Al}_{2} \mathrm{O}_{3}\right)$, which results in the formation of a glassy phase with low viscosity that fills the pores within the brick structure, reducing porosity and increasing thermal conductivity. In addition, the concentrations of $\mathrm{SiO}_{2}(46.92 \%)$ and $\mathrm{Al}_{2} \mathrm{O}_{3}(15.45 \%)$ in the clay soil were within the recommended range of $20 \%$ to $50 \%$ for $\mathrm{SiO}_{2}$ and $10 \%$ to $20 \%$ for $\mathrm{Al}_{2} \mathrm{O}_{3}$ of brick making $[15,16]$.

Table 3. Chemical components and oxides found in clay soil and BG.

\begin{tabular}{ccc}
\hline \multirow{2}{*}{ Chemical Components } & \multicolumn{2}{c}{ Concentration } \\
\cline { 2 - 3 } & Clay Soil (\%) & BG (\%) \\
\hline $\mathrm{Na}$ & 0.14 & 4.37 \\
\hline $\mathrm{Mg}$ & 0.48 & 0.39 \\
\hline $\mathrm{Al}$ & 7.08 & 0.92 \\
\hline $\mathrm{Si}$ & 21.86 & 24.02 \\
\hline $\mathrm{Ca}$ & 0.16 & 8.94 \\
\hline $\mathrm{Ti}$ & 0.66 & 0.04 \\
\hline $\mathrm{Cr}$ & 0.02 & 0.16 \\
\hline $\mathrm{Fe}$ & 5.22 & 0.67 \\
\hline $\mathrm{Na}_{2} \mathrm{O}$ & 0.33 & 8.47 \\
\hline $\mathrm{SiO}_{2}$ & 46.92 & 52.13 \\
\hline $\mathrm{K}_{2} \mathrm{O}$ & 3.53 & 0.91 \\
\hline $\mathrm{Fe}_{2} \mathrm{O}_{3}$ & 5.64 & 0.69 \\
\hline $\mathrm{CaO}$ & 0.18 & 10.01 \\
\hline
\end{tabular}




\subsection{Sieve Analysis}

Sieve analysis was employed to determine the particle size distribution of the BG powder. As shown in Figure 5 of the particle size distribution, most BG powder passed through the $0.075 \mathrm{~mm}$ sieve, and the passing rate was around $60 \%$. Consequently, the crushed BG can be seen as fine sand based on the Australian Standard [17].

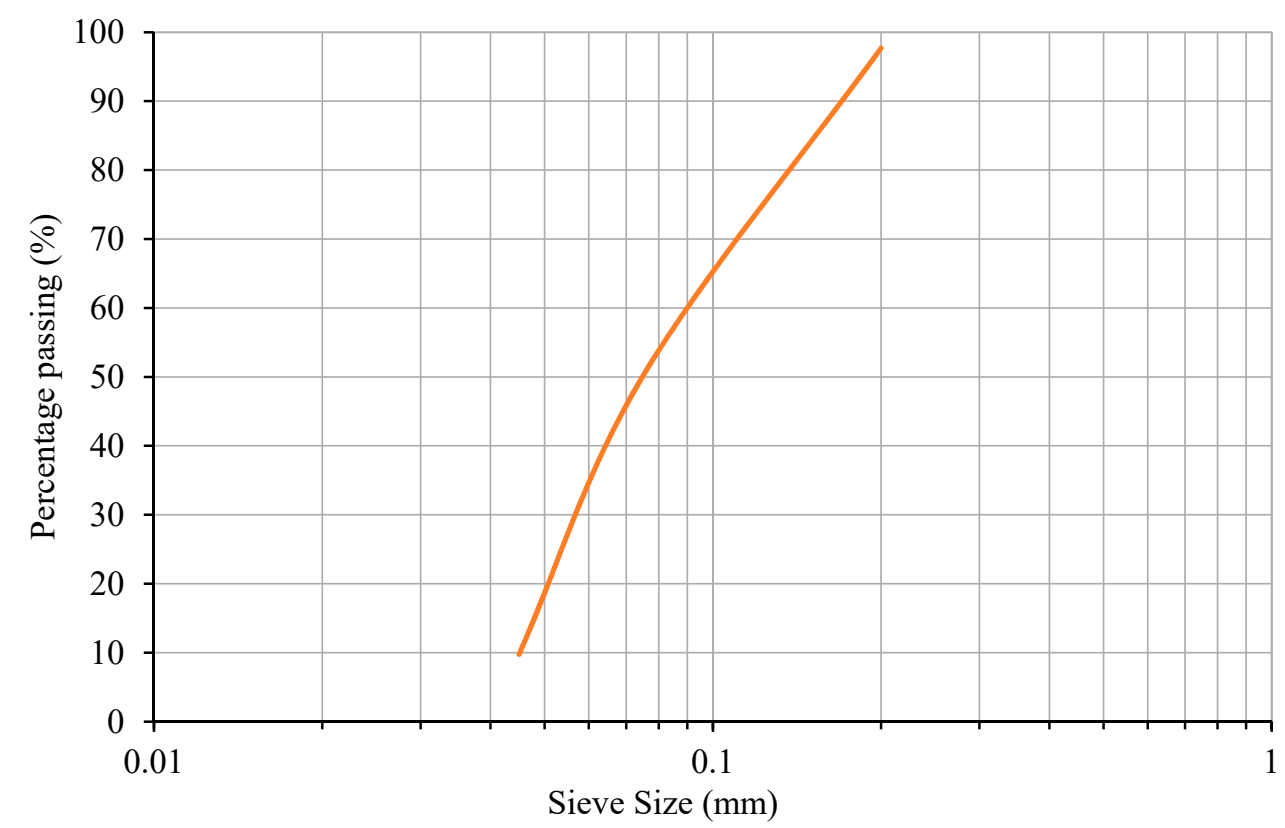

Figure 5. Particle size distribution.

\subsection{Compressive Strength}

Compressive strength is an essential parameter to determine the quality of bricks. According to previous studies regarding bricks in most low-rise buildings, the acceptable compressive strength is about $5 \mathrm{MPa}$ [1]. Thus, it can be easily seen that all of the tested bricks overwhelmingly satisfy this limit, as shown in Figure 6. In addition, by comparing the compressive strength of the controlled and BG contained samples, it can be seen that set number $3\left(10 \%\right.$ BG firing at $\left.950{ }^{\circ} \mathrm{C}\right)$ depicted similar compressive strength results with the control samples. The results demonstrated that compressive strength has a linear relationship with the firing temperature. The compressive strength decreased from $113 \mathrm{MPa}$ to $99 \mathrm{MPa}$ with the decrease in firing temperature. Demir [18] and Abdeen [19] reported similar results, which indicated that an increase in firing temperature improved the compressive strength of the bricks manufactured with BG because high concertation of silicon $(\mathrm{Si})$ helps form a glassy phase at a temperature above $850{ }^{\circ} \mathrm{C}$, reducing the porosity. As a result, the compressive strength increased. 


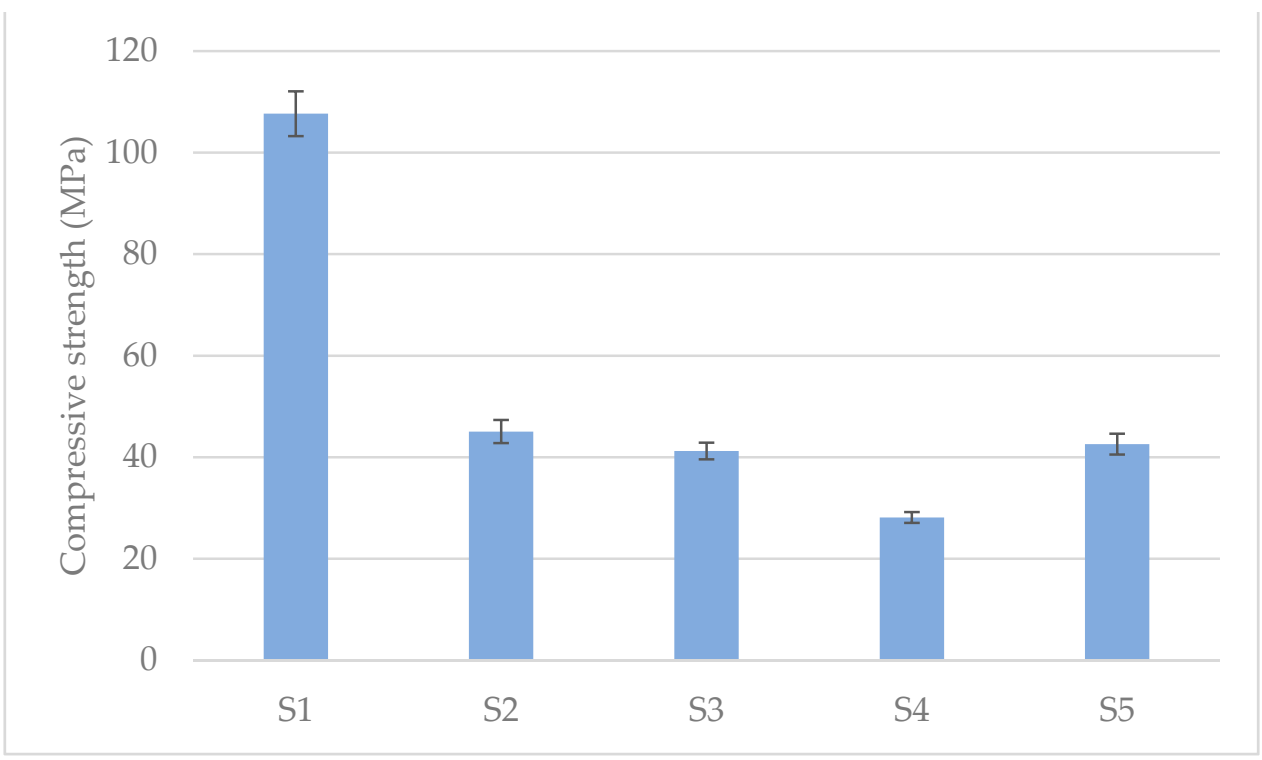

Figure 6. Compressive strength results. (S1-10\% BG fired at $1050{ }^{\circ} \mathrm{C}, \mathrm{S} 2-10 \% \mathrm{BG}$ fired at $1000{ }^{\circ} \mathrm{C}$, S3-10\% BG fired at $950{ }^{\circ} \mathrm{C}$, S4-10\% BG fired at $900{ }^{\circ} \mathrm{C}$, S5-Control $0 \%$ BG fired at $1050{ }^{\circ} \mathrm{C}$ ).

\subsection{The Shrinkage Properties}

Table 4 depicted the shrinkage properties of the manufactured bricks. The average initial drying shrinkage, firing shrinkage, and total shrinkage values of four brick samples from each set were measured and represented in height and diameter. The shrinkage properties of bricks are essential due to their direct impact on the stress on the ceramic body, and as a result, will increase the likelihood of shrinkage cracks occurring [20]. As can be seen, the BG did not increase the shrinkage values excessively at $1050{ }^{\circ} \mathrm{C}$. The average firing shrinkage decreased with the decreased firing temperature, whether measuring from diametric or height. The total shrinkage values of the control samples were nearest to set number 2, which contained $10 \%$ BG powder and was fired at $1000{ }^{\circ} \mathrm{C}$. In addition, the total shrinkage of a good quality brick should be less than $8 \%$ [6]. By using $8 \%$ as the limit and comparing the results, the performance of all the manufactured bricks is satisfactory.

Table 4. Shrinkage test results.

\begin{tabular}{|c|c|c|c|}
\hline Type of Shrinkage & Type of Brick & Diametric (\%) & Height (\%) \\
\hline \multirow{5}{*}{ Initial drying shrinkage } & $\mathrm{S} 110 \% \mathrm{BG} 1050^{\circ} \mathrm{C}$ & 1.34 & 1.26 \\
\hline & $\mathrm{S} 210 \% \mathrm{BG} 1000^{\circ} \mathrm{C}$ & 1.38 & 1.23 \\
\hline & S3 $10 \%$ BG $950^{\circ} \mathrm{C}$ & 1.30 & 1.02 \\
\hline & S4 $10 \%$ BG $900^{\circ} \mathrm{C}$ & 1.44 & 1.20 \\
\hline & S5 $0 \%$ control BG $1050^{\circ} \mathrm{C}$ & 2.07 & 1.27 \\
\hline \multirow{5}{*}{ Firing shrinkage } & $\mathrm{S} 110 \% \mathrm{BG} 1050^{\circ} \mathrm{C}$ & 5.91 & 2.80 \\
\hline & $\mathrm{S} 210 \% \mathrm{BG} 1000^{\circ} \mathrm{C}$ & 5.36 & 2.17 \\
\hline & S3 $10 \%$ BG $950^{\circ} \mathrm{C}$ & 2.97 & 1.29 \\
\hline & S4 $10 \%$ BG $900^{\circ} \mathrm{C}$ & 0.75 & 0.51 \\
\hline & S5 $0 \%$ control BG $1050^{\circ} \mathrm{C}$ & 3.97 & 2.10 \\
\hline \multirow{5}{*}{ Total shrinkage } & $\mathrm{S} 110 \% \mathrm{BG} 1050^{\circ} \mathrm{C}$ & 7.24 & 4.06 \\
\hline & S2 $10 \%$ BG $1000^{\circ} \mathrm{C}$ & 6.74 & 3.40 \\
\hline & S3 $10 \%$ BG $950^{\circ} \mathrm{C}$ & 4.27 & 2.31 \\
\hline & S4 $10 \%$ BG $900^{\circ} \mathrm{C}$ & 2.19 & 1.71 \\
\hline & S5 $0 \%$ control BG $1050^{\circ} \mathrm{C}$ & 6.04 & 3.37 \\
\hline
\end{tabular}

\subsection{Thermal Conductivity}

Kazmi et al. [21] reported that density, porosity, waste glass content, and the firing temperature are the main factors that affect thermal performance [21]. As shown in Table 5, 
average dry density decreased with the decrease in firing temperature, and the thermal conductivity decreased with the decrease in firing temperature. The thermal conductivity decreased from $0.84 \mathrm{~W} / \mathrm{mk}$ at $1050{ }^{\circ} \mathrm{C}$ to $0.62 \mathrm{~W} / \mathrm{mK}$ at $900{ }^{\circ} \mathrm{C}$. In addition, the results proved that the density affected the thermal conductivity performance, which is consistent with the previous study results of Kazmi et al. [12]. Kazmi et al. reported the thermal conductivity decreased from $0.6 \mathrm{~W} / \mathrm{mK}\left(1375 \mathrm{kgm}^{-3}\right)$ to $0.55 \mathrm{~W} / \mathrm{mK}\left(1358.37 \mathrm{kgm}^{-3}\right)$. In this study, the thermal conductivity decreased from $2450.84 \mathrm{~W} / \mathrm{mK}\left(2300 \mathrm{kgm}^{-3}\right)$ to $0.62 \mathrm{~W} / \mathrm{mK}\left(2000 \mathrm{kgm}^{-3}\right)$.

Table 5. Thermal conductivity.

\begin{tabular}{ccc}
\hline Type of Brick & $\begin{array}{c}\text { Average Thermal } \\
\text { Conductivity (W/mK) }\end{array}$ & $\begin{array}{c}\text { Average Dry Density } \\
\left(\mathbf{k g m}^{-3}\right)\end{array}$ \\
\hline $\mathrm{S} 110 \% \mathrm{BG} 1050{ }^{\circ} \mathrm{C}$ & 0.84 & 2300 \\
\hline $\mathrm{S} 210 \% \mathrm{BG} 1000^{\circ} \mathrm{C}$ & 0.81 & 2200 \\
\hline $\mathrm{S} 310 \% \mathrm{BG} 950^{\circ} \mathrm{C}$ & 0.81 & 2100 \\
\hline $\mathrm{S} 410 \% \mathrm{BG} 900^{\circ} \mathrm{C}$ & 0.62 & 2000 \\
\hline $\mathrm{S} 50 \%$ control BG $1050{ }^{\circ} \mathrm{C}$ & 0.49 & 2100 \\
\hline
\end{tabular}

\subsection{XRD Analysis of Brick Specimens Fired at Different Temperatures}

XRD was utilised to identify the main crystalline phases (Figure 7). Quartz, Rutile, Hematite, Tridymite, Pseudorutile, and Muscovite were the main phases in the brick specimens incorporating $0 \%$ and $10 \%$ BG at various temperatures $\left(900,950,1000\right.$, and $1050{ }^{\circ} \mathrm{C}$ ). Above $1000{ }^{\circ} \mathrm{C}$, Hematite $\left(\mathrm{Fe}_{2} \mathrm{O}_{3}\right)$ was present. The reason is that after the breakdown of the phyllosilicates, iron recrystallises, resulting in the formation of iron oxides, which was consistent with previous results [22]. Additionally, the peaks of pseudorutile disappeared above $1000{ }^{\circ} \mathrm{C}$.

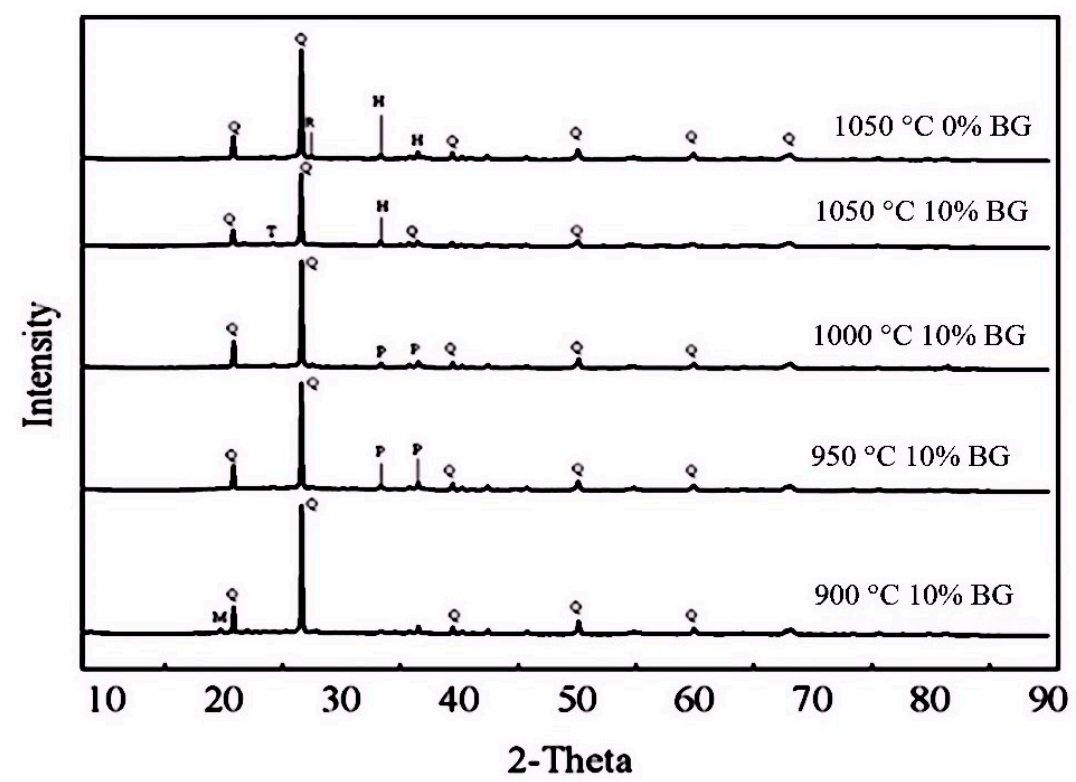

Figure 7. XRD patterns. (Q-Quartz, R-Rutile, H-Hematite, T-Tridymite, P-Pseudorutile, and M-Muscovite).

\subsection{Water Absorption}

\subsubsection{Initial Rate of Absorption}

The IRA test was used to determine the amount of water in grams absorbed in one minute over the bed face of the brick. Water infiltration is an essential parameter of brick durability. As a result, a high value of IRA should be avoided because it can cause adverse 
effects on durability. According to [23], the IRA should be within the range of 0.2 to $5 \mathrm{~kg} / \mathrm{m}^{2} / \mathrm{min}$ to provide good bond strength. Hence, all of the manufactured bricks in this study satisfied this requirement based on Table 6. A high value of IRA should be avoided because it can cause adverse effects on durability. In addition, it can be seen from Table 6 that set number 3 with a $10 \%$ BG content, fired at $900{ }^{\circ} \mathrm{C}$, demonstrated an IRA result of $1.94 \mathrm{~kg} / \mathrm{m}^{2}$ similarly to set number $5\left(0 \% \mathrm{BG}\right.$ content and fired at $\left.1050^{\circ} \mathrm{C}\right)$ control sample of $1.72 \mathrm{~kg} / \mathrm{m}^{2}$.

Table 6. IRA Values.

\begin{tabular}{|c|c|}
\hline Sample & Average IRA (Gross) $\left(\mathrm{kg} / \mathrm{m}^{2}\right)$ \\
\hline $\mathrm{S} 110 \% \mathrm{BG} 1050{ }^{\circ} \mathrm{C}$ & 0.89 \\
\hline $\mathrm{S} 210 \% \mathrm{BG} 1000^{\circ} \mathrm{C}$ & 1.31 \\
\hline S3 $10 \%$ BG $950{ }^{\circ} \mathrm{C}$ & 1.94 \\
\hline S4 $10 \%$ BG $900{ }^{\circ} \mathrm{C}$ & 3.58 \\
\hline S5 $0 \%$ control BG $1050{ }^{\circ} \mathrm{C}$ & 1.72 \\
\hline
\end{tabular}

\subsubsection{Cold Water $24 \mathrm{~h}$ Immersion Test and $5 \mathrm{~h}$ Boiling Water Test}

The results of the cold-water immersion test and boiling water test were shown in Table 7. The lowest cold-water absorption rate $(0.43 \%)$ was achieved by adding $10 \%$ BG into bricks and firing at $1050{ }^{\circ} \mathrm{C}$ (set 1), which was much lower than the results for control bricks $(7.1 \%)$. The results regarding the five-hour absorption in boiling water in Table 7 indicated that control bricks absorbed four times the boiling water than bricks that contained $10 \% \mathrm{BG}$ and were fired at $1050{ }^{\circ} \mathrm{C}$ (set 1). Based on the required absorption value in ASTM C62 (Table 8), it can be seen that the saturation coefficient (SC) results of all tested bricks were below the maximum required absorption value of $17 \%$ (required for building bricks exposed to severe weathering (SW)) [24]. As a result, the tested bricks' water absorption complied with the criteria for ASTM C62 building brick. Furthermore, the brick sample fired at $1050^{\circ} \mathrm{C}$ absorbed less water than the brick sample fired at $950^{\circ} \mathrm{C}$, which resulted from the increase in porosity that caused a rise in the bricks' water absorption. At temperatures above $850^{\circ} \mathrm{C}$, the glass phase increases, and the density increases, so the water absorption rate decreases. The water absorption results investigated were consistent with previous studies $[18,21,25,26]$.

Table 7. Cold water $24 \mathrm{~h}$ immersion test results.

\begin{tabular}{cccc}
\hline Sample & $\mathbf{W}_{\mathbf{i}}{ }^{*}$ (Average) & $\mathbf{W}_{\mathbf{b}}{ }^{*}$ (Average) & $\begin{array}{c}\text { Saturation } \\
\text { Coefficient }\end{array}$ \\
\hline $\mathrm{S} 110 \% \mathrm{BG} 1050{ }^{\circ} \mathrm{C}$ & 0.43 & 1.85 & 0.23 \\
\hline $\mathrm{S} 210 \% \mathrm{BG} 1000^{\circ} \mathrm{C}$ & 3.30 & 4.87 & 0.68 \\
\hline $\mathrm{S} 310 \% \mathrm{BG} 950{ }^{\circ} \mathrm{C}$ & 9.42 & 10.84 & 0.87 \\
\hline $\mathrm{S} 410 \% \mathrm{BG} 900^{\circ} \mathrm{C}$ & 12.02 & 13.59 & 0.88 \\
\hline $\mathrm{S} 50 \%$ control BG $1050{ }^{\circ} \mathrm{C}$ & 7.10 & 8.55 & 0.83 \\
\hline
\end{tabular}

* Note: $\mathrm{W}_{\mathrm{i}}$ = percentage cold water immersion absorption of the specimen; $\mathrm{W}_{\mathrm{b}}$ = percentage boiling water absorption of the specimen; Saturation coefficient $=$ the ratio between the $\mathrm{W}_{\mathrm{i}}$ and $\mathrm{W}_{\mathrm{b}}$.

Table 8. ASTM C 62 specifications for building brick.

\begin{tabular}{cccc}
\hline Grade & Max A24, Cold & Max A5, Boil & Max SC \\
\hline SW & - & 17 & 0.78 \\
\hline MW & - & 22 & 0.88 \\
\hline NW & - & No limit & No limit \\
\hline
\end{tabular}




\subsection{Colour}

From a building, fabricator, and customer perspective, the colour of the brick produced is essential. Table 9 illustrated pictures of the manufactured brick specimens. The colour of controlled bricks was darker than the colour of bricks containing $10 \%$ BG due to the addition of BG (the concentration of iron oxides increased). In addition, the colour of the brick specimens darkened as the firing temperature increases, which is in line with the argument stated in the review paper from Xin et al. [27]. The concentration of iron oxide has the most significant effect on colour. Regardless of its natural colour, almost any form of iron-containing clay will appear red when exposed to oxidizing fire because of the formation of ferrous oxides.

Table 9. Manufactured Brick specimens.
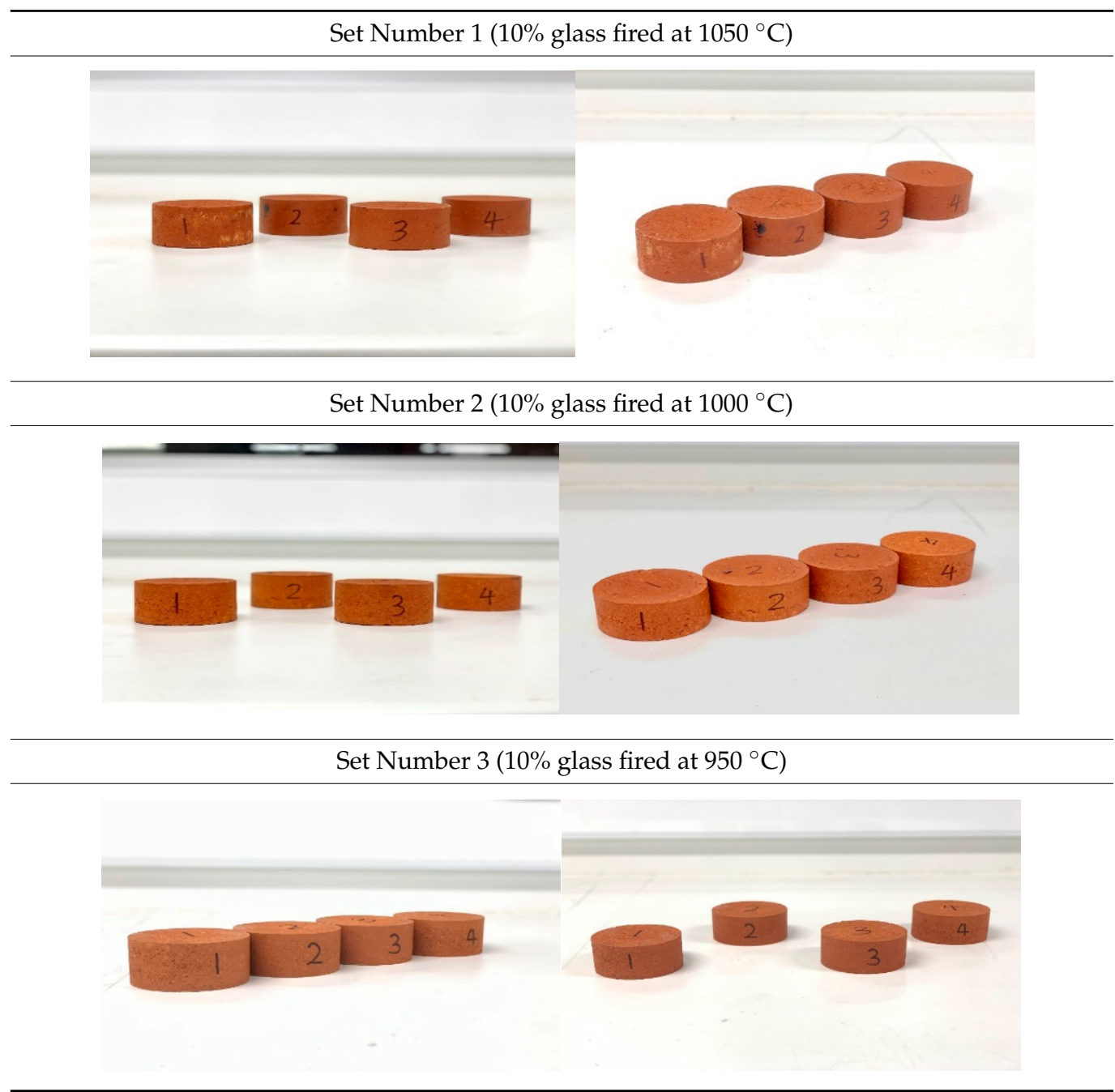
Table 9. Cont.

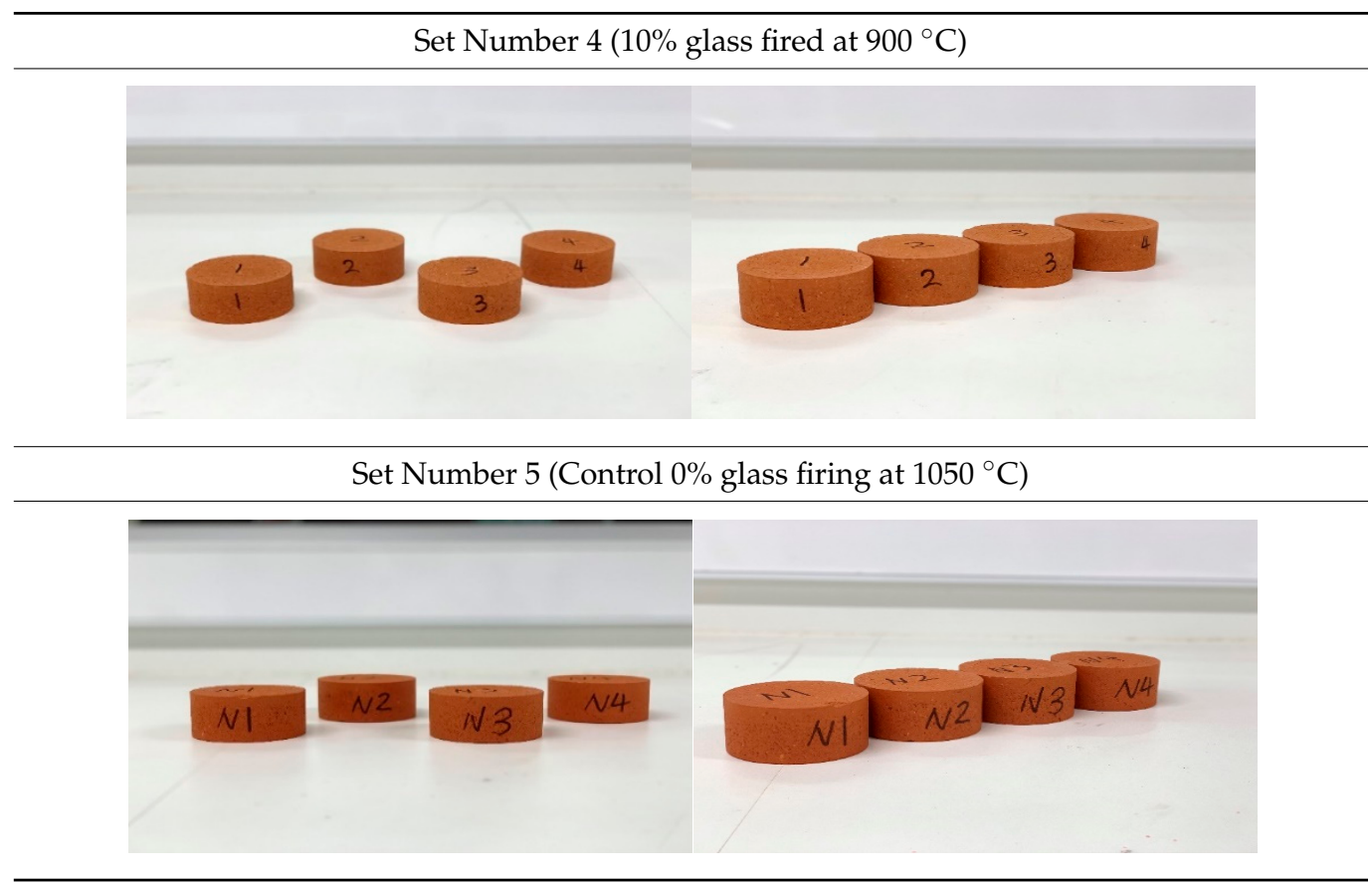

\section{Conclusions}

This study investigated whether beer bottle glass (BG) can be recycled in fired-clay bricks and investigated the relationship between the firing temperature and the corresponding physical and mechanical properties and thermal conductivity. The BG incorporated bricks were compared with the control samples ( $0 \%$ CWG), and conclusions were drawn as to whether the physio-mechanical properties of the bricks remained the same, improved, or worsened. As can be seen from the test results, the compressive strength of BG-incorporated bricks decreased with the decreasing firing temperature. However, the compressive strength was still above the limit of $5 \mathrm{MPa}$. The maximum compressive strength $(113.93 \mathrm{MPa})$ was achieved with the addition of $10 \% \mathrm{BG}$ at a firing temperature of $1050{ }^{\circ} \mathrm{C}$. The test results regarding water absorption indicate that all tested bricks satisfied the maximum recommended absorption value of $17 \%$, which is required for building bricks exposed to severe weathering (SW). Thermal conductivity test results proved that the density and firing temperatures affected thermal conductivity performance, consistent with the previous study results. Additionally, all of the manufactured bricks in this study satisfied the requirements of Australian standards.

Finally, the production of fired clay bricks relies on extensive mining of natural resources and non-renewable raw materials, which caused the clay shortage and the growing pollution problem. Further, the current recycling techniques practised for waste glass are limited, resulting in a stockpile catastrophe. Therefore, recycling waste glass in fired clay bricks can solve a growing world waste calamity, minimise the stockpile in landfills, and potentially reduce firing temperatures to $900^{\circ} \mathrm{C}$ because BG helps forming the glass phases at a temperature above $850{ }^{\circ} \mathrm{C}$ and the glass phases help to improve the properties of the bricks (based on the results in this study, the physical/mechanical properties of $10 \%$ BG-containing bricks fired at $900{ }^{\circ} \mathrm{C}$ still satisfied the requirements of Australian standards).

Author Contributions: Conceptualization, A.M.; methodology, Y.X. and H.K.; formal analysis, Y.X.; investigation, Y.X., Y.D. and Y.L.; data curation, Y.X.; writing-original draft preparation, Y.X., Y.D. and Y.L.; writing-review and editing, A.M., H.K., D.R., B.P. and P.T.; supervision, A.M., D.R., B.P. and P.T.; project administration, A.M.; All authors have read and agreed to the published version of the manuscript. 
Funding: This research received no external funding.

Institutional Review Board Statement: Not applicable.

Informed Consent Statement: Not applicable.

Data Availability Statement: All data are displayed in the manuscript.

Acknowledgments: This work is part of an ongoing study on recycling waste in construction materials. The authors would like to thank Visy Australia Pty Ltd., PGH Bricks and Pavers (Victoria, Australia) and RMIT University for their in-kind support.

Conflicts of Interest: The authors declare no conflict of interest.

\section{References}

1. Mohajerani, A.; Kadir, A.A.; Larobina, L. A practical proposal for solving the world's cigarette butt problem: Recycling in fired clay bricks. Waste Manag. 2016, 52, 228-244. [CrossRef]

2. PWC. Extractive Resources in Victoria: Demand and Supply Study 2015-2050 Final Report; Earth Resouses Victoria: Melbourne, VIC, Australia, 2016

3. Nath, A.J.; Lal, R.; Das, A.K. Fired bricks: $\mathrm{CO}_{2}$ emission and food insecurity. Glob. Chall. 2018, 2, 1700115. [CrossRef]

4. Chiang, K.-Y.; Chou, P.-H.; Hua, C.-R.; Chien, K.-L.; Cheeseman, C. Lightweight bricks manufactured from water treatment sludge and rice husks, J. Hazard. Mater. 2009, 171, 76-82. [CrossRef] [PubMed]

5. Alonso-Santurde, R.; Viguri, A.; Coz, J.; Andrés, A.J.C. Recycling of foundry by-products in the ceramic industry: Green and core sand in clay bricks. Constr. Build. Mater. 2012, 27,97-106. [CrossRef]

6. Mohajerani, A.; Ukwatta, A.; Jeffrey-Bailey, T.; Swaney, M.; Ahmed, M.; Rodwell, G.; Setunge, S. A Proposal for Recycling the World's Unused Stockpiles of Treated Wastewater Sludge (Biosolids) in Fired-Clay Bricks. Buildings 2019, 9, 14. [CrossRef]

7. Vlasova, M.; Márquez, A.P.A.; González-Molina, V.; Trujillo-Estrada, A.; Kakazey, M. Development of an energy-and water-saving manufacturing technology of brick products. Sci. Sinter. 2018, 50, 275-289. [CrossRef]

8. Phonphuak, N.; Kanyakam, S.; Chindaprasirt, P. Utilisation of waste glass to enhance physical-mechanical properties of fired clay brick. J. Clean. Prod. 2016, 112, 3057-3062. [CrossRef]

9. NetBalance. Market Summary-Recycled Glass; Sustainability Victoria: Melbourne, VIC, Australia, 2014.

10. Standards Australia. Methods of Testing Soils for Engineering Purposes Soil Compaction and Density Tests; (AS/NZS 1289.5.1.1); SAI Global Limited: Chicago, IL, USA, 2017.

11. Standards Australia. Masonry Units and Segmental Pavers and Flags; (AS/NZS 4456.4); SAI Global Limited: Chicago, IL, USA, 2003.

12. Standards Australia. Methods of Testing Soils for Engineering Purposes-Soil Classification Tests (Determination of the Linear Shrinkage of a Soil-Standard Method); (AS 1289.3.4.1); SAI Global Limited: Chicago, IL, USA, 2008.

13. Standards Australia. Masonry Units and Segmental Pavers and Flags_Methods of Test Determining Initial Rate of Absorption (Suction); (AS/NZS 4456.17); SAI Global Limited: Chicago, IL, USA, 2003.

14. Standards Australia. Masonry Units and Segmental Pavers and Flags-Methods of Test Determining Water Absorption Properties; (AS/NZS 4456. 14); SAI Global Limited: Chicago, IL, USA, 2003.

15. Velasco, P.M.; Ortíz, M.M.; Giró, M.M.; Velasco, L.M. Fired clay bricks manufactured by adding wastes as sustainable construction material-A review. Constr. Build. Mater. 2014, 63, 97-107. [CrossRef]

16. Kurmus, H.; Mohajerani, A. Energy savings, thermal conductivity, micro and macro structural analysis of fired clay bricks incorporating cigarette butts. Constr. Build. Mater. 2021, 283, 122755. [CrossRef]

17. Standards Australia. Soil Classification Tests-Determination of the Particle Size Distribution of a Soil-Standard Method of Analysis by Sieving; (AS 1289.3.6.1); SAI Global Limited: Chicago, IL, USA, 2009.

18. Demir, I. Reuse of waste glass in building brick production. Waste Manage. Res. 2009, 27, 572-577. [CrossRef] [PubMed]

19. Abdeen, H.H. Properties of Fired Clay Bricks Mixed with Waste Glass. J. Sci. Res. Rep. 2016, 13, 1-9. [CrossRef]

20. Demir, I. Effect of organic residues addition on the technological properties of clay bricks. J. Waste Manag. 2008, 28, 622-627. [CrossRef] [PubMed]

21. Kazmi, S.M.S.; Munir, M.J.; Wu, Y.F.; Hanif, A.; Patnaikuni, I. Thermal performance evaluation of eco-friendly bricks incorporating waste glass sludge. Constr. Build. Mater. 2018, 172, 1867-1880. [CrossRef]

22. Chandrasekaran, E.; Viruthagiri, G.; Praveen, P. The effect of temperature on ceramic bricks with replacing waste glass in low volume ratio. Int. J. Adv. Sci. Res. 2018, 3, 79-86.

23. Standards Australia. Masonry Structures; (AS 3700); SAI Global Limited: Chicago, IL, USA, 2018.

24. ASTM International. ASTM C62 Standard Specification for Building Brick (Solid Masonry Units Made from Clay or Shale); ASTM International: West Conshohocken, PA, USA, 2017.

25. Federico, L.M. Effects of Waste Glass Addition on the Properties of Fired Clay Brick. Ph.D. Dissertation, McMaster University, Hamilton, ON, Canada, 2006. 
26. Dondi, M.; Guarini, G.; Raimondo, M.; Zanelli, C. Recycling PC and TV waste glass in clay bricks and roof tiles. Waste Manag. 2009, 29, 1945-1951. [CrossRef] [PubMed]

27. Xin, Y.; Kurmus, H.; Mohajerani, A.; Smith, J.V. Possible recycling of waste glass in sustainable fired clay bricks: A review. Int. J. Geomate 2021, 20, 57-64. [CrossRef] 